\title{
CUESTIONES SOBRE LEGITIMACION EN EL PROCESO CONSTITUCIONAL DE AMPARO
}

\author{
POR \\ JOSE ALMAGRO NOSETE \\ Catedrático de Derecho procesal \\ Facultad de Derecho. UNED
}

SUMARIO

I. Pré́mbulo.-II. La tUTELA JURISDiccional de LOS INTERESES JURÍDicos: A) Consideración general. B) Intereses tutelables. C) Los intereses legitimos.-III. NECESIDAD DE UN RÉGIMEN DE LEGITIMACIONES PROCESALES: $10^{\circ}$ (la titularidad presunta de un derecho negativo). $2 .^{\circ}$ (sigue; la invocación de un interés jurídico). 3.० (sigue; la invocación de intereses generales o públicos: Ministerio Fiscal, Defensor del Pueblo, corporaciones). $4 .^{\circ}$ (sigue; los intereses sociales, colectivos y difusos: órganos públicos y «organizaciones» legitimadas).-IV. LA LEgITIMACIÓN PARA RECURRIR EN AMPARO ANTE EL TRIBUNAL de Garantías ConstTtucionales.-V. La leggitimación Para Recurrir en amparo en México y Alemania (R. F.): A) En México. B) En Alemania (R. F.).-VI. La legrTIMACIÓN EN NUESTRO ACTUAL PROCESO CONSTTTUCIONAL DE AMPARO: A) La legitimación en el texto constitucional: a) Personas naturales. b) Personas jurídicas. c) Defensor del Pueblo. d) Ministerio Fiscal. B) La legitimación en la Ley Orgánica del Tribunal Constitucional: a) El cambio de lenguaje. b) Interpretación del concepto «interés legítimo» en el amparo constitucional: 1. Intereses propios. 2. Intereses solidarios: 2.1. Intereses generales. 2.2. Intereses colectivos. 2.3. Intereses difusos. 2.4. Intereses comunes de ámbito reducido.

\section{PREAMBULO}

El proceso constitucional de amparo ofrece una rica gama de soluciones legitimantes para su incoación y válida prosecución. Tentado se está de intentar, a partir del examen concreto de su problemática, la construcción de las bases para fundamentar una teoría general de la legitimación, empeño que desde hace tiempo me preocupa, pero que debo relegar a mejor ocasión, aunque no deje en ésta de apuntar ideas y sugerencias al filo de las cuestiones concretas que suscitan los preceptos correspondientes ${ }^{1}$.

1 Esta preocupación arranca de mis primeros intentos generalizadores de los conceptos básicos del Derecho procesal. Algunos problemas de esta naturaleza fueron tratados en mi memoria pedagógica. Parte de estas ideas las recogí en mi trabajo sobre «El libre acceso como derecho a la jurisdicción» (Revista de la Facultad de Derecho de la Universidad 
El tema de la legitimación es siempre apasionante, pues tras él subyace la verdadera protección de los derechos e intereses jurídicos y, más al fondo, la filosofía política y jurídica de un ordenamiento ${ }^{2}$. Pensemos, por ejemplo, en las diferencias de legitimación que se dan en el ámbito del Derecho privado entre los ordenamientos que se inspiran en modelos de democracia clásica y los de las llamadas democracias populares.

Si el Derecho romano fue caracterizado como un «sistema de acciones», el Derecho actual puede definirse como un «sistema de legitimaciones». La actio ejercitada purgaba los posibles vicios impeditivos de la sentencia durante la fase in iure del proceso seguida ante el magistrado; otorgada la acción en esta fase, durante la siguiente (apud iudicem), el iudex (u órganos equivalente) se vinculaba a dictar una sentencia (salvo que hiciera uso del non liquet). La cognitio extra ordinem supuso la función de ambas fases ${ }^{3}$.

Durante el Derecho intermedio el tratamiento de la legitimatio ad causam, en algunos supuestos (cesión, herencia), motivaba una justificación o acreditamiento previo, de carácter probatorio, configurado en el proceso común como una «excepción dilatoria» cuyos vestigios llegan a nuestra casi centenaria Ley de Enjuiciamiento Civil ${ }^{4}$, en la que se confunden problemas de prueba con el concepto puro de legitimación.

Complutense, núm. 37, vol. XIV, Madrid, 1970, págs. 25 y ss.); en él, bajo el epígrafe «8. La medida del derecho a la jurisdicción (legitimación)», tomaba posiciones en este tema. Mis tesis en torno a este concepto hacen decir a Cordón Moreno (autot de una importante monogtafía sobre legitimación) que está fundamentalmente de acuerdo con las mismas, «ya que es la única que nos permite adentrarnos en el estudio unitario de la legitimación" (La legitimación en el proceso contencioso-administrativo, Pamplona, 1979, página 29). Más tarde he insistido sobre algunos de estos aspectos, proyectándolos en la órbita de los nuevos intereses carentes de acción (Almagro, Nuevos borizontes del derecho a la justicia, Madrid, 1976).

2 Véase cap. IV, «Los participantes en el litigio», de la obra Derecho procesal civil soviético, México, 1971, publicada bajo la dirección de M. A. Gurvich. Vigoriti señala acertadamente que es un tema, primero, de política legislativa, y sólo en segundo lugar un problema técnico. Cita las opiniones de Calamandrei, Mandrioli y Vocino sobre este particular en términos coincidentes (Interessi collettivi e processo, Milán, 1979, pág. 66).

${ }_{3}$ Cfr. García Garrido, Derecho privado romano, I, Instituciones, Madrid, 1979, páginas $115 \mathrm{y}$ ss.

${ }^{4}$ Cfr. Gómez Orbaneja, Derecho procesal civil, vol. I, Madrid, 1977, pág. 137. Critica este autor dicha solución por entender que es inescindible la titularidad subjetiva del derecho y la existencia objetiva del mismo. De otra parte, Gutiérrez de Cabíedes sostiene que «en ningún supuesto es tan evidente como en éste la posibilidad de tratar procesalmente una institución que por su naturaleza afecta al proceso. Puede exigirse perfectamente, como lo hace la ley, un acreditamiento previo de la regularidad subjetiva en la transmisión del derecho y como cosa independiente la alegación y prueba de la existencia objetiva del derecho afirmados (Estudios de Derecho procesal, Pamplona, 1974, pág. 271). Personalmente, no entiendo la mezcolanza entre legitimación y prueba de la legitimación. $\mathrm{O}$, dicho en otros términos, la confusión entre legitimación y prueba del derecho afirmado (quiere decirse prueba de los hechos constitutivos de la fattispecie del derecho afirmado) o prueba del interés afirmado (quiere decirse prueba de los hechos configurados por el ordenamiento como relevantes a los efectos de objetivar una posición jurídica subjetiva que permite obtener determinadas consecuencias jurídicas). La legitimación es un concepto puramente jurídico tno «contaminado» por los hechos relacionados con el fondo, en tanto en cuanto muestra la consistencia de la pretensión material, porque indica si la correlación jurídica entre sujeto-objeto es conforme a Derecho, y, por tanto, si es admisible la consideración de la misma de acuerdo con las peticiones deducidas. De aquí que pueda estimarse el tema 
En el Derecho moderno son clásicas las aportaciones de Helewig y de Chiovenda, que profundizaron en estos problemas. Al primero se debe, en palabras de un autor, «la más acabada construcción de la teoría de la legitimación», y al segundo el estudio, a partir de la doctrina alemana, de los fenómenos de «sustitución procesal», considerados por Prieto-Castro como supuestos de «desplazamiento de la legitimación» 5 .

Con todo, las investigaciones de más peso sobre este tema se han circunscrito al ámbito del proceso civil ${ }^{6}$. Las cuestiones de legitimación se han soslayado en el proceso penal, donde estos problemas se han tratado sin especial relieve dentro de la teoría de la acción o de las partes ${ }^{7}$ o con un sentido diferente ${ }^{8}$, aunque no falten indicaciones sobre el concepto ${ }^{9}$.

La necesidad de ampliar el concepto clásico de legitimación, elevando a categorías generales supuestos contemplados como extraordinarios, surge por imperativos del estudio del proceso contencioso-administrativo, pues referido aquél en el proceso civil (como legitimación ordinaria) a la afirmación congruente con la petición deducida de la titularidad del derecho (sin que falten ejemplos de legitimaciones concedidas en función de un interés), el desarrollo de la doctrina del interés legitimante adquiere toda su importancia ante esta manifestación jurisdiccional en cuanto anuladora de actos o disposiciones administrativas y legales ${ }^{10}$.

No han faltado entre los procesalistas españoles trabajos sobre este punto ${ }^{11}$, aunque sean éstos todavía escasos. Y falta, desde luego, una teoría general ampliamente desarrollada.

legitimatorio como un presupuesto de fondo que requiere tratamiento previo a la entrada en el mismo.

${ }^{5}$ La obra de Helewig (System des deutschen Civilprocessrecht, I, Leipzig, 1912; hay reimpresión de 1968) fue analizada, junto con otras importantes aportaciones de dicho autor en estos aspectos, por Prieto-Castro en su Tratado de Derecho procesal civil, tomo II, Madrid, 1952 (véase nota 203 bis —pág. 261- y «bibliografía general» -pág. 81-). Cfr. Chiovenda, Principi de Diritto processuale civile, Nápoles, 1923 (trad. de Casais Santaló, tomo II, Madrid, 1925, pág. 27), e Istituzioni di Diritto processuale civile, Nápoles, 1936 (trad. de Gómez Orbaneja, tomo II, Madrid, 1940, pág. 283):

${ }^{6}$ Cfr. Prieto-Castro, cap. IX del Tratado de Derecho procesal, cit.; Gómez Orbaneja, Derecbo procesal civil, cit.; especialmente útil es su trabajo sobre «Legitimación y representación», en Estudios de Derecho bistórico y moderno, Madrid, 1947; Guasp, Derecbo procesal civil, tomo I, Madrid, 1968, pág. 185.

7 Véase Gómez Orbaneja, Comentarios a la Ley de Enjuiciamiento Criminal, tomo II, vol. I, Barcelona, 1971, que incluye estas cuestiones bajo el epígrafe «La titularidad en la acción penal», pág. 208.

${ }^{8}$ Fenech (Derecho procesal penal, tomo I, Barcelona-Madrid, 1960, pág. 316) ha relacionado el concepto de legitimación en el Ministerio Fiscal con las causas que motivan su deber de abstención, criterio que hace extensivo al abogado del Estado. En otra obra (El proceso penal, Madrid, 1978, pág. 60) considera la legitimación del imputado como una cuestión de hecho.

9 Parcas son éstas en la obra de Prieto-Castro y Gutiérrez de Cabíedes, Derecho procesal penal, Madrid, 1978, págs. 65-69, y en Gómez Orbaneja-Herce, Derecbo procesal penal, Madrid, 1968, pág. 42. Cfr. también Viada-Aragoneses, Curso de Derecho procesal penal, tomo I, Madrid, 1974, págs. 106, 132, 141 y 154.

${ }_{10}$ Cfr. González Pérez, Derecho procesal administrativo, tomo II, Madrid, 1966, página 267; García de Enterría y T.-R. Fernández, Curso de Derecho administrativo, tomo II, Madrid, 1977, pág. 514.

${ }^{11}$ Cfr. Cordón Moreno, La legitimación en el proceso contencioso-administrativo, cit. 
Una teoría general de legitimación, para que sea fructuosa, pasa, a mi juicio, necesariamente por las siguientes bases:

1. ${ }^{\mathrm{a}}$ Reconocimiento de un derecho general de accionar de carácter abstracto o derecho a la jurisdicción que explica por medio del concepto complementario de legitimación la vinculación del juez competente a dictar una sentencia de fondo (sea ésta estimatoria o absolutoria). No es de extrañar, mientras se mantenga un concepto de la acción en sentido concreto, como derecho a una sentencia favorable o simplemente de fondo, que la acción se confunda con la legitimación y que este último concepto pueda considerarse «redundante» o «inútil» ${ }^{12}$.

2. ${ }^{a}$ Consideración de la legitimación como una condicio iuris de orden público procesal (por tanto, apreciable de oficio) cuyo cumplimiento se exige al titular del derecho a la jurisdicción para vincular, en un proceso concreto donde ejercite este derecho, al órgano jurisdiccional competente a dictar una sentencia de fondo, sea ésta favorable o desfavorable al sujeto legitimado.

3. ${ }^{a}$ Estimación de que el contenido de esta condición consiste en la alegación de un interés jurídicamente relevante ${ }^{13}$ al que el Derecho erige en razón justificativa de las consecuencias jurídicas que se pretenden. Este interés puede considerarse como obvio e ínsito en la propia dinámica de las relaciones jurídicas, de manera que la afirmación de la titularidad de un derecho subjetivo presupone aquél. En otros casos, el interés no dimana de ninguna relación jurídica preexistente, sino que se relaciona con una situación jurídica originadora de algún perjuicio o privativa de algún beneficio ${ }^{14}$.

${ }^{12}$ Cfr. Gómez Orbaneja-Herce, Derecbo procesal civil, cit., pág. 137. Este mismo escepticismo sobre la utilidad del concepto se pone de relieve en las palabras finales con que cerró su documentada y brillante conferencia sobre legitimación y representación, ya citada: «Evitemos todo concepto al que no podamos dar un contenido preciso.»

${ }_{13}$ No confundo este interés con otros conceptos que utiliza la doctrina (interés de obrar, causa de la acción) para justificar la licitud y la utilidad del derecho a la jurisdicción. $\mathrm{El}$ interés que tiene en cuenta el legislador para otorgar o reconocer a determinadas posiciones subjetivas legitimación procesal es un interés jurídicamente objetivado que funciona como causa legitimante en cuanto que confiere a quien lo invoque la posibilidad jurídica de obtener una sentencia de fondo sobre los efectos jurídicos pretendidos consecuentes con aquella posición subjetiva, que debe ser favorable si prueba lo que afirma y su interpretación jurídica coincide con la que establezca el juez. Los motivos concretos que le induzcan a actuar no cuentan en principio para el Derecho. Sólo cuando estos motivos revelen un fraude o una ausencia de verdadero interés final (causa inexistente) podrán ser tenidos en cuenta por el Derecho.

${ }_{14}$ Morón Palomino llega a la consecuencia de que «el interés en la obtención de una tutela jurisdiccional que se hace necesaria constituye el criterio determinante de la legitimación procesal activa» tras reflexionar sobre la legitimación por sustitución; previamente ha trascendido el concepto de legitimación del proceso civil a la fórmula del interés directo que establece el artículo 28 de la LRJCA, y ha señalado cómo en un Código «tan evolucionado como es el del Estado de la Ciudad del Vaticano el artículo 2 dice que puede accionar cualquiera que tenga un interés para cuya tutela sea necesaria la intervención de los órganos jurisdiccionales» («Reflexiones acerca de la legitimación procesal activa», en Estudios en bomenaje al profesor Prieto-Castro, tomo II, Madrid, 1979, pág. 488). También el concepto de interés es reconocido por el nuevo Code de Procedure civile francés, de 5 de diciembre de 1975, como causa legitimante; el artículo 31 dice que: «L'action est ouverte a tous aux qui ont un intérêt légitime au succès ou au rejet d'une prétention, sous reserve des cas dans lesquels la loi attribue le droit de agir aux seules personnes qu'elle qualifie 
4. Insuficiencia de la alegación del interés legitimante para considerar cumplida la condición impuesta, pues es preciso que el órgano jurisdiccional constate si la posición subjetiva que la ley atribuye a quien afirma ese concreto interés (o derecho) es jurídicamente suficiente para pedir los efectos jurídicos que se pretenden.

5. Finalmente, necesidad de considerar que el tema de la legitimación comporta siempre una quaestio iuris y no una quaestio facti, que, aunque afecta a los argumentos jurídicos de fondo, puede determinarse con carácter previo a la resolución del mismo, pues únicamente obliga a establecer si efectivamente guarda coherencia jurídica la posición subjetiva que se invoca en relación con las peticiones que se deducen.

\section{LA TUTELA JURISDICCIONAL DE LOS INTERESES JURIDICOS}

\section{A) Consideración general}

La tutela jurisdiccional se ha ligado tradicionalmente a la protección de los derechos. Los derechos configuran el aspecto activo en la estructura de la relación jurídica, establecida en razón de una determinada composición de intereses, objetivada en la norma jurídica que la rige. Cuando se pretende, rectius, la satisfacción del derecho se actúa en función de los intereses prevenidos por ésta en favor del titular. Tutelar el derecho significa también tutelar los intereses que aquel derecho asegura. Mas no siempre la protección jurisdiccional se refiere a los intereses ínsitos en la vocación de satisfacción del derecho. Cabe que determinados intereses sean objetivados como dignos de tutela jurisdiccional sin necesidad de que respondan a la satisfacción de un derecho preexistente.

Toda persona o sujeto de derecho disfruta de un estado de hecho, configurado como una esfera de actuación lícita que debe ser respetada, es decir, no inquietada o perturbada. En términos jurídicos, esta esfera de desenvolvimiento de la persona tiene carácter posesorio y debe estar al resguardo de agresiones antijurídicas. Los intereses que motivan el desenvolvimiento y actuación de la persona pueden devenir afectados por actuaciones ajenas. El ordenamiento jurídico puede y debe tutelar estos intereses otorgándoles una protección jurisdiccional para impedir que actuaciones ilegítimas incidan sobre la esfera del sujeto o para procurar que legítimamente se interese en relaciones jurídicas ajenas que, sin embargo, le afectan. Puede, pues, decirse que a estas

pour élever ou combattre une prétention ou pour défendre un intérêt determiné.» $\mathrm{Ha}$ prevaleciḍo, pues, la tesis de Morell, según la cual la única condición de receptibilidad impuesta por la ley al ejercicio de la acción es la existencia de un interés en favor de quien actúa conforme a la antigua fórmula «Pas d'intérêt, pas d'action» (Nouveau Code de procedure civile, comentado por Blanc, París, s/f., pág. 46). Unos apuntes sobre la teoría general de la legitimación con diversificación posterior a toda suerte de procesos en Fazzalari, Istituzioni di Diritto processuale, Padua, 1979, pág. 146. 
situaciones jurídicas constituyentes ${ }^{15}$ por actos extraños de modificaciones en su estatuto jurídico o de perturbaciones en su estado de hecho, se les confiere relevancia en orden a establecer medios de defensa para evitar o reparar los perjuicios que las mismas originen.

\section{B) Intereses tutelables}

Los intereses son múltiples y de naturaleza varia. Es muy difícil, por no decir imposible, reconducir la rica gama de éstos a clasificaciones cerradas ${ }^{16}$.

Sin embargo, pueden establecerse clasificaciones útiles en razón de determinadas contraposiciones y matizaciones significativas para el Derecho: 1) Intereses individuales e intereses generales. Los primeros son los que determinan la satisfacción de necesidades o conveniencias de cada sujeto que redundan en su beneficio exclusivo. Los generales son aquellos que conciernen a una comunidad o colectividad, de manera que aunque la satisfacción de las necesidades o conveniencias que los explican repercuten, en la alícuota correspondiente, en beneficio de los sujetos que componen esa colectividad, normalmente, comportan limitaciones o sacrificios impuestos a intereses individuales; 2) Intereses privados y públicos. Este par de adjetivos se corresponde tradicionalmente con los dos anteriores, de manera que, por término habitual, lo individual es privado y lo general es público. En verdad que la filosofía política y jurídica del liberalismo ha estado impregnada de esta doble corespondencia; no obstante, la crisis de la distinción entre lo privado y lo público, se ha acentuado en las últimas décadas, ante el desarrollo y recíproca influencia intersubjetiva de las relaciones sociales ${ }^{17}$; 3) Intereses personales e intereses sociales (los intereses colectivos y difusos). Este fenómeno de complejidad creciente de las interacciones sociales, digno de consideración jurídica, lleva a la estimación de otra matización en las bipolaridades que apuntamos. Al lado de los intereses personales, entendidos como privativos del sujeto, surgen los intereses sociales que introducen una calificación específica a los intereses personales que son comunes a un grupo o categoría de sujetos. No es fácil fijar un concepto unívoco sobre los intereses sociales. En realidad no se diferencian

${ }^{15}$ Guasp, en su obra Derecho (Madrid, 1971), estudia las situaciones jurídicas como contenidos de las relaciones jurídicas en cuanto integran la esencia del devenir de éstas. Define la situación jurídica como «un emplazamiento típico de la relación de derecho en cierto grado determinado de su vida». Especial importancia tienen en cuanto al punto que examinamos las situaciones que llama creativas en cuanto constituyentes de nuevos estados jurídicos (pág. 177).

${ }_{16}$ Los intereses son contemplados por Guasp como los modos específicos que describen el modo de funcionar del Derecho. Si la relación jurídica constituye la estructura del Derecho, los intereses son su función, de manera que el dinamismo de lo jurídico corresponde a éstos. Se revela así la inaprehensibilidad del concepto que en puridad no refleja más que una posición de un sujeto respecto de un objeto (ob. cit., pág. 272).

${ }_{17}$ Destaca Cappelletti el ocaso de la tradicional dicotomía público-privado, su irrealidad en la sociedad contemporánea y el nuevo sentido que debe inspirar la tutela de los intereses explicativos de la conflictualidad en masa ( Appunti sulla tutela giurisdizionale di interessi collettivi o diffusi», pág. 192, publicado en Le azioni a tutela di interessi collettivi. Atti del convegno di studio, Padua, 1976). 
de lo que son intereses de cada uno de los miembros del grupo, o categoría, o colectivo de mayor o menor extensión afectado, más que en el sentido comunitario que une a los sujetos afectados y en la posible consideración objetiva de dichos intereses, como causa de tutela diferenciada.

En la doctrina italiana, estos intereses, con matizaciones según los casos, reciben la denominación de intereses colectivos, y con esta expresión, que cuenta ya con una amplia literatura, se estudian los problemas que origina la tutela jurídico material y procesal de los mismos. Al tiempo, como términos indiferenciados o sinónimos, en algunos casos se emplea la denominación de intereses difusos. Sin embargo, los autores tratan de encontrar y fijar delimitaciones que permitan, con efectos útiles, la distinción.

Como afirma Vigoriti, los intereses colectivos significan un grado de «organización» ${ }^{18}$, sin que esta idea haga necesariamente referencia a una formalización definitiva de dicha organización. En cambio, los intereses difusos, que sustancialmente no se distinguen de los colectivos, responderían a una fase más fluida del proceso de agregación de los intereses individuales hasta obtener la consistencia que origina la organización.

Mención aparte merece el «interés legítimo» por la repercusión que el mismo tiene como razón legitimante y su acogida constitucional, tanto en lo que respecta a la jurisdicción ordinaria como en lo que se refiere a la jurisdicción constitucional y, en especial, al proceso de amparo.

Todos los intereses examinados son legítimos en cuanto jurídicos y aceptables, por tanto, por el ordenamiento como dignos de tutela. La legitimidad, pues, de un interés no significa más que su juridicidad. Lo que ocurre es que es éste un concepto de importación al que conviene privarle de sus adherencias foráneas en tanto éstas respondan a ideas ya sobrepasadas.

\section{C) Los intereses legítimos}

Al constitucionalizar el derecho a la jurisdicción, la redacción del precepto correspondiente incluye junto a la tradicional tutela de los derechos, la de los intereses legítimos (art. 24 de la Constitución). Y más adelante, al regular las legitimaciones para recurrir ante el Tribunal Constitucional, se faculta «a toda persona natural o jurídica que invoque un interés legítimo» para interponer el recurso de amparo (art. 162.1.b de la Constitución).

El origen de este concepto jurídico de tango constitucional debe situarse en el artículo 24 de la Constitución italiana, que establece un derecho general a la tutela judicial de los propios derechos e intereses legítimos ${ }^{19}$.

${ }^{18}$ Cfr. Vigoriti, Interessi collettivi e processo. La legitimazione ad agire, cit., pág. 61.

${ }^{19}$ Sobre. los defectos técnicos de la fórmula empleada por la Constitución española vigente, véase Almagro, «El Derecho procesal en la nueva Constitución», en Revista de Derecbo procesal iberoamericana, núm. IV, octubre-diciembre 1979, pág. 858. La referencia a la tutela de los derechos e intereses legítimos podría haber sido mejorada si se hubiera antepuesto el verbo «pretender» para entender la posición subjetiva de quien reclama justicia y recibe sólo tutela procesal porque carece de los derechos o intereses legítimos que afirma en su favor como ciertos. 
Ahora bien: este concepto de procedencia ius administrativa (empleado también por nuestra jurisprudencia, aunque la LRJCA utilice la expresión de interés directo) nace en el marco de una estructura jurídica muy condicionada por las particularidades del ordenamiento italiano. Habrá, pues, que inculcar a nuestros juristas y jueces la conveniencia de romper aquellos condicionamientos históricos que motivan el desarrollo del mismo en otro ordenamiento jurídico para salvarlo del dogal interpretativo ajeno, recreándolo en un sistema jurídico diferente. Reclamamos, pues, en algún sentido, para los juristas españoles la virginidad interpretativa del concepto constitucional, que debe ser adaptado a las características propias, desprovisto de gangas que impidan su plena virtualidad. Actualmente, la doctrina procesal italiana debate sobre el alcance de este concepto de intereses legítimos respecto de los intereses colectivos y difusos, pues, enmarcado en el ámbito interpretativo de los intereses individuales, su proyección a una esfera más dilatada no deja de tener dificultades. Poco a poco, sin embargo, se resquebraja jurisprudencialmente la exigencia de la individualidad del interés y se abren paso interpretaciones más progresivas ${ }^{20}$.

No debe tampoco ocurrirnos que por la inercia interpretativa del concepto vinculado por la jurisprudencia contencioso-administrativa, como un aspecto del interés directo a intereses individuales, comencemos nosotros a recorrer ahora un largo camino ya recorrido por otros. A eso me refiero cuando hablo de la necesidad de respetar toda la potencialidad interpretativa del concepto interés legítimo, desde la óptica constitucional ${ }^{21}$.

Veamos el sentido de los intereses legítimos en la doctrina administrativista española y la mezcolanza que se opera entre legitimación e interés a efectos de fijar en su momento ias relaciones entre ambos conceptos y las diferencias entre situación de derecho material y legitimación entendida como puro concepto procesal.

La noción de interés legítimo surgió en Italia para justificar la bipartición de jurisdicciones. Mientras la jurisdicción ordinaria se ocupa de la tutela de los derechos civiles y políticos, aunque esté interesada la Administración Pública y los actos que afecten a los mismos emanen del poder ejecutivo o de autoridad administrativa, la jurisdicción administrativa (Consiglio di Stato) decide sobre los recursos interpuestos por los interesados contra los actos administrativos que se consideren lesivos de un interés legítimo. Se recogía así, adaptándola a peculiaridades propias la tradición francesa de los recours pour excés de pouvoir, instaurados ante el «Conseil d'État», en interés de la legalidad, aunque la jurisprudencia de dicho órgano se haya resistido a considerar

${ }^{20} \mathrm{Cfr}$. Vittorio Denti, que en este sentido trae a colación las diferencias de tratamiento entre el caso de la asociación "Italia nostra», en cuyos fines se encuentra la tutela del patrimonio artístico, del ambiente urbano y natural, y el caso de los operadores turísticos del golfo de Gaeta. En «telazione introduttiva», Le azioni a tutela di interessi collettivo, cit., pág. 4.

${ }_{21}$ La legitimidad del interés ha venido considerándose por la jurisprudencia contenciosoadministrativa como uno de los requisitos del interés directo, que ha de ser siempre personal, del recurrente. Véase Cordón Moreno, La legitimación en el proceso contencioso-administrativo, cit., pág. 116. Nada obsta, sin embargo, a que la legitimidad del interés pueda referirse a otros intereses que no sean exclusivamente los personales. 
que bastara el mero interés ciudadano y exigiera consecuentemente un interés concreto como base de la legitimación.

Para González Pérez no es necesario, en punto a legitimación en materia contencioso-administrativa (conforme a la Ley vigente), que el interés directo sea legítimo, aunque debe ser personal y actual; en definitiva, este calificativo manifiesta un carácter innato al interés, a saber: que ha de ser protegido por el ordenamiento jurídico ${ }^{22}$.

Considera García Enterría la equivocidad de este concepto, pese a los esfuerzos de la doctrina italiana para encontrar una clave satisfactoria, y estima que ninguna de las teorías propuestas «acierta a dar una cabal explicación del fenómeno como tal» ${ }^{23}$.

No obstante estas lógicas reservas sobre la ambigüedad del concepto, es lo cierto que también la noción de interés directo, acogida por la LRJCA, remite a dificultades en algún sentido análogas. En definitiva, la problemática más llamativa que subyace en toda esta cuestión es la referente al carácter meramente procesal o netamente sustancial del interés. Todos los artilugios que se inventen para adoptar posiciones híbridas están a mi entender condenados a la esterilidad, pues lo que hacen es trasladar a otro lugar la vieja polémica de las relaciones entre la acción y el derecho material. El concepto de legitimación es una andadura de carácter procesal $y$, por tanto, instrumental, un paso más en cuanto al logro de la sentencia de fondo que resuelve - según la imagen sattiana- en el misterio del juicio la soldadura entre lo procesal y lo material. Lo que pasa es que este concepto procesal dice de la relación entre sujeto que pide y efectos jurídicos que pretende según el derecho material a título de hipótesis, nacida en un proceso concreto.

Esta problemática se ha proyectado, en el orden contencioso-administrativo, en la polémica en torno a la concepción objetiva de esta manifestación jurisdiccional, cuyo fin sería la abstracta tutela de la legalidad; y la concepción subjetiva, cuyo fin sería la tutela de situaciones jurídicas individuales. $\mathrm{Y}$, sin embargo, creo que el problema no debe enfocarse por la atribución a los procesalistas de teorías que no sostienen. El interés tiene que ser cierto y real para que prospere la pretensión. La legitimación es un instrumento que se funda en la afirmación de aquel interés en tanto éste sea hábil para producir los efectos jurídicos requeridos.

${ }^{22}$ Cfr. González Pérez, Derecbo procesal administrativo, tomo II, Madrid, 1966, página 281.

${ }_{23}$ «De hecho - dice-, ninguna ninguna ha aceptado a asegurar una extensión sustancial de la tutela judicial a los ciudadanos, conviniendo todos los autores en que la situación de la justicia administrativa en Italia, ligada a esa famosa bipartición teórica entre derechos e intereses legítimos, no es satisfactoria, como se conviene en que lo es, sin embargo, la fórmula paralela del excés de pouvoir francés, configurada pragmáticamente» (Curso de Derecbo administrativo; cit., pág. 40). 


\section{NECESIDAD DE UN REGIMEN DE LEGITIMACIONES PROCESALES}

La necesidad de un régimen de legitimaciones viene impuesta por la colocación que, en cada ordenamiento jurídico, se reconozca u otorgue a determinados sujetos como portadores y gestores de intereses jurídicos y por el grado de respeto que establezca en cuanto a la libertad de cada sujeto (disponibilidades jurídicas). Hablando a efectos de reconducción al absurdo, un derecho a la jurisdicción, carente de supuestos legitimantes, que condujera indefectiblemente a meras sentencias de forma no tiene sentido. Pero un derecho a la jurisdicción, acompañado de una legitimación abierta para todos los casos posibles, llevaría a un trastrueque total del ordenamiento jurídico y a la pérdida de la libertad.

En la selección de los sujetos portadores del interés es donde radica la concepción del ordenamiento jurídico. Diversas consideraciones caben a este propósito:

1. abviamente, el titular de un derecho subjetivo, como portador individualizado del máximo interés, dispone del mismo y tiene la facultad de hacerlo efectivo, de ejercitarlo o de realizarlo. Cuando el derecho es negado, perturbado o lesionado, incumbe al mismo la disposición sobre su defensa. Ocurre, sin embargo, que, por estar en tela de juicio la existencia o virtualidad del derecho, la tutela judicial del mismo exige un mecanismo técnico, complementario del derecho a la jurisdicción que denominamos legitimación, consistente en la afirmación de la titularidad y en la correlación de la misma con los efectos jurídicos pedidos. El juicio de derecho sobre dicha correlación o coherencia permite decir si el sujeto está o no legitimado. La legitimación es un a priori en cuanto al fondo del asunto y tiene que ver con el fondo del asunto en cuanto determina la posibilidad jurídica del pronunciamiento sobre el mérito. No siempre, sin embargo, es el propio sujeto que afirma o de quien se afirma una titularidad jurídica el que actúa en su propio nombre en el proceso. El instrumento de la «representación» (perteneciente a la teoría general del Derecho) permite que el representante actúe en el proceso por el representado, vinculando los efectos de la sentencia a éste. La representación, en sus dos versiones (voluntaria y legal), afecta más propiamente al tema de la capacidad procesal, pero no excluye el de legitimación, al menos en cuanto que subsiste el problema de la legitimación ordinaria del representado ${ }^{24}$.

Mediante la sucesión procesal en casos de transmisión inter vivos o mortis causa de los derechos litigiosos se permite, cumplidos los requisitos exigidos, que la legitimación originaria de la parte sucedida se traslade a la parte sucesora ${ }^{25}$. Cabe también que un sujeto actúe en nombre e interés propio una relación jurídica ajena; se habla entonces de sustitución procesal; acertadamente define Serra Domínguez la sustitución como «el ejercicio por una persona en

${ }^{24}$ Las relaciones entre representación y legitimación han sido estudiadas con agudas observaciones por Gómez Orbaneja en Legitimación y representación, cit.

${ }_{25}$ Cfr. Ramos Méndez, La sucesión procesal, Barcelona, 1974, pág. 28. 
nombre e interés propio de los derechos de otra ligada con la primera por un vínculo jurídico» ${ }^{26}$.

En realidad, en estos casos el sustituto actúa un derecho propio a disponer de un derecho ajeno. A efectos de legitimación se puede tener en cuenta la superposición entre la legitimación del sustituto y la legitimación del sustituido, de manera que si la afirmación del primero respecto del vínculo con el segundo no tiene virtualidad jurídica o la titularidad que atribuye al segundo carece de la eficacia que pretende, no se cumplen los requisitos de la legitimación.

Finalmente, determinadas relaciones jurídicas privadas o «estados» (matrimonio, capacidad), en cuanto proyectan su influencia a áreas más dilatadas que la subjetiva o intersubjetiva, pueden motivar el reconocimiento por el ordenamiento de intereses autónomos respecto de los mismos, ora porque se considere el interés general o público de tales situaciones, ora porque se estime la afección que dichos estados producen, desde el punto de vista jurídico, a otras personas integradas en círculos de vinculación más o menos amplios. Se explicarían así las legitimaciones establecidas en favor de otras personas en los procesos, por ejemplo, matrimoniales o de estado y capacidad. Sobre el carácter sustancial o procesal del interés, abundaremos en los apartados siguientes.

2. ${ }^{a}$ Si el derecho subjetivo perfecto supone el máximo grado de interés, no todos los intereses que merezcan tutela jurídica tienen que estar formalizados como derechos subjetivos perfectos. Enseña Guasp que, en el iter de las relaciones jurídicas, determinadas situaciones jurídicas originarias (o sea, situaciones de nacimiento de la relación jurídica) consisten en actividades antijurídicas que causan una lesión jurídica entre sujetos que no están ligados por el derecho ${ }^{27}$. Esta lesión no tiene que afectar a un derecho preexistente. Puede consistir en la privación de un beneficio o de una situación de ventaja, o en la causación de un perjuicio o simplemente en la extorsión de una expectativa, atinentes a la lícita esfera de actuación de un sujeto, con la consiguiente frustración de sus intereses legítimos. Estos intereses legítimos son de naturaleza sustancial o material, no procesal. El ordenamiento jurídico debe tutelar estos intereses, reconociendo al sujeto los medios de evitación o de reparación de los efectos perniciosos de la lesión. El reconocimiento de un poder de esta naturaleza al portador de tales intereses (que revisten carácter personal) apareja la lógica legitimación procesal de quien los afirma, en tanto en cuanto la descripción del interés y su relación con el acto lesivo permite establecer a priori que si efectivamente el acto fuera antijurídico, aquél no tiene que soportar los perjuicios o privación de ventajas que el mismo produzca. Este tipo de legitimación es la que se reconoce en materia contencioso-administrativa respecto de las pretensiones dirigidas a la anulación de actos que no son conforme a Derecho, aunque el destinatario del mismo no sea el sujeto afectado. La lesión de un derecho o de un interés es un problema de prueba; con razón establece una sentencia (20 de febrero de 1965) que la cuestión de si hay o no lesión

\footnotetext{
${ }^{2}$ Serra Domínguez, «Intervención de terceros en el proceso», en Estudios de Derecho procesal, Barcelona, 1969, pág. 231.

${ }^{7}$ Cfr. Guasp, Derecho, cit., pág. 194.
} 
de derechos o intereses exige un estudio de fondo que no puede realizarse por mera vía de inadmisibilidad. La legitimación, en cambio, tanto se base en la invocación de un derecho como de un interés, es una quaestio iuris; ocurre que así como la legitimación, basada en un derecho, ofrece unas perspectivas más tasadas de interpretación por la mayor cristalización de la categoría jurídica, de manera que el contenido de la relación jurídica correspondiente suele estar predeterminado, la legitimación, basada en la invocación de un interés, dado el carácter fluido de éstos y su multiformidad, requiere en muchas ocasiones de un esfuerzo jurisprudencial, caso por caso, para determinar la posibilidad jurídica del pronunciamiento. En caso de duda, sobre la legitimación ésta no debe ser obstáculo para entrar en el fondo. Acertadamente se mantiene por la jurisprudencia que el concepto deliberadamente amplio de interés directo ha de aplicarse con un criterio laxo que, en situaciones dudosas, evite el cerrar el acceso a la reclamación (sentencia de 12 de noviembre de 1965). En definitiva, la legitimación no es más que la posibilidad jurídica del pronunciamiento de fondo, apreciada por el órgano jurisdiccional, con base en la invocación de un interés tutelado jurídicamente justificativo, en su caso, de la posición subjetiva de la parte en relación con el pedimento de conformidad con el ordenamiento jurídico.

3. Mas no sólo los derechos e intereses individualizados erigen a sus portadores en sujetos aptos para pedir tutela judicial de fondo, con la consiguiente legitimación a favor de quienes invoquen éstos con las demás circunstancias exigibles. Los intereses generales y públicos, en cuanto tutelados por el Derecho, exigen también protección judicial. Ahora bien: dijimos que la característica de estos intereses es que no se refieren a un sujeto en particular, sino a todos en general. La determinación, por tanto, del portador del interés no puede individualizarse por propia definición. Son posibles dos soluciones extremas y una tercera intermedia. La primera consiste en atribuir a cada portador del interés (en la alícuota que le corresponde) legitimación para actuar ante los órganos jurisdiccionales el interés de todos en cuanto indivisible. Como quiera que estos intereses generales afectan en mayor o en menor grado a círculos comunitarios, más extensos y menos intensos o menos extensos y más intensos, según los casos, cabe que se legitime a todos los sujetos (acción popular) o sólo al grupo colectivo más afectado (acción vecinal). El Derecho procesal administrativo reconoce en determinados supuestos este tipo de legitimaciones. Así establece la acción popular en materia urbanística o la acción vecinal en determinadas cuestiones de régimen local. En realidad, no puede afirmarse que en esta clase de legitimaciones se produzca una total desvinculación de la situación de derecho material considerada para reconocer aquéllas. Ocurre, no obstante, que la razón legitimadora está tan embebida en la cualidad con que comparece el sujeto que, a efectos prácticos, puede pasar inadvertida su relación con el objeto. La acción popular muestra su aptitud para la impugnación de disposiciones u ordenanzas de carácter general, así como para la consecución de sanciones respecto de actos o acciones que impliquen grave atentado contra la legalidad, de trascendencia para la regular convivencia ciudadana (acción popular en materia penal). La segunda solución consiste en privar de legitimación a todos los afectados (son razones de prudencia política 
las que juegan) e instituir un órgano público, específicamente legitimado para actuar en justicia en defensa de estos intereses. Es la función del Ministerio Fiscal (Ministerio Público con monopolio de la acción penal en otros Estados). Esta legitimación institucional, de neto carácter público, se vincula al ejercicio de un oficio; aunque en la trama jurídico-material subyazca la relación con el interés hecho valer, ésta se difumina y se asume por la misma configuración del oficio público (de todos modos la falta de legitimación puede ser acusada; piénsese, por ejemplo, en los delitos cuya persecución exige denuncia condicionante del ofendido). De aquí que Carnelutti pudiera decir que «a la parte privada el poder le deriva del interés; al Ministerio Público el interés le deriva del poder» ${ }^{28}$. Por eso, el traslado, sin más, de las figuras aplicadas o construidas por el Derecho procesal civil de la representación o de la sustitución al Ministerio Fiscal no son satisfactorias. De una parte, su actuación, en cuanto no sirve a intereses propios, se asemeja a la del representante, de la que, no obstante, se diferencia porque su poder no dimana directamente del representado; ni siquiera puede considerarse como representante legal, ya que (salvo en los casos en que así actúa por causa de interés público en representación interina de menores, ausentes o incapaces o cuando ejercita la acción civil en el proceso penal) los efectos de su actuación no se individualizan para alguien en particular. Empleando esquemas de Derecho privado, sólo metafóricamente puede decirse que represente a la sociedad o al Estado. De otra parte, se asemeja al sustituto por cuanto actúa en virtud de un poder propio, aunque la disimilitud proviene de que no gestiona intereses propios; sucede, pues, que los esquemas del Derecho civil no son aplicables (como además resulta lógico) a las funciones de este oficio público. A mi juicio, su misión se explica como una modalidad de la representación pública, género amplio, de la que una de sus especies la constituye la representación política, que en alguna de sus formas no siempre exige el procedimiento electoral. La tercera solución -como ya se habrá adivinado- resulta de una combinación entre ambas. Es el criterio seguido en nuestro ordenamiento respecto de las legitimaciones en Derecho procesal penal. El Ministerio Fiscal, en efecto, tiene el deber de ejercitar la acción penal para la persecución de los delitos públicos. Mas también los ciudadanos españoles pueden ejercitar esta acción sin necesidad de haber sido ofendidos por el delito (los ofendidos a fortiori también pueden ejercitar dicha acción, sin necesidad de prestar caución). He sostenido en otras ocasiones, frente a la tesis favorable al monopolio del Ministerio Fiscal, que la acción popular cumple una misión de control político a impedir que aquel monopolio pueda transformar en algún caso el principio de legalidad que debe regir la actuación del Ministerio Fiscal en un principio de oportunidad. Esta función, supletoria y vigilante de la posibilidad de ejercicio de la acción popular, se observa mejor en aquellos ordenamientos que, como el italiano, no conocen en materia contencioso-administrativa acciones populares directas, aunque admiten acciones populares supletorias o correctivas, establecidas para tutelar un derecho o interés de la Administración o para tutelar un interés público frente

${ }^{28}$ Cfr. Carnelutti, «Poner en su puesto al Ministerio Público», en Cuestiones sobre el proceso penal (trad. Sentís Melendo), Buenos Aires, 1961, pág. 213. 
a la Administración ${ }^{29}$. Y éste es el sentido de la acción popular subrogatoria establecida por el artículo 371 de la Ley española de Régimen Local. Cabe también que la defensa de estos intereses generales (o menos generales en cuanto sectoriales o corporativos) se atribuya por ministerio de la ley a determinadas entidades de Derecho público que cumplen funciones análogas en este aspecto a las del Ministerio Fiscal. Así, en la LJRCA (art. 28.b) la impugnación directa de disposiciones de carácter general de la Administración Central incumbe sólo «a las entidades, corporaciones e instituciones de Derecho público y cuantas entidades ostentaren la representación o defensa de intereses de carácter general o corporativo, siempre que la disposición impugnada afectare directamente a los mismos». En esta línea de defensa de los intereses generales debe también situarse al Defensor del Pueblo respecto de las legitimaciones que tiene reconocidas en materia constitucional, muy en especial las que le incumben en orden a la impugnación de las normas con fuerza de ley inconstitucionales.

4. ${ }^{a}$ Quedan por considerar, finalmente, los intereses que denominamos sociales o colectivos, con la variante de los difusos. Estos intereses, como ya afirmamos, afectan a áreas más o menos amplias; son intereses de categorías, clases o grupos. Como manifestación de éstos deben considerarse los intereses profesionales. La peculiaridad de estos intereses en orden a su protección y defensa es que, considerados en el conjunto del colectivo a que afectan, ofrecen matices distintos (son como una entidad nueva) de cuando se examinan aisladamente. En particular, cabe que cada interés de los que se suman al conjunto sea tutelable, pero razones de ineficacia o de dificultad sociológica práctica en la consecución de tales intereses en solitario motivan que en el orden material, aunque no formal, queden indefensos. Los mecanismos procesales del futuro deben responder a las exigencias de esta tutela diferenciada. Los conceptos de comunidad incidental, litis consorcio, alcance y eficacia de la cosa juzgada y, por supuesto, legitimación, deben superar su carga de obsolescencia.

En principio hay varias maneras de enfocar la temática de la protección judicial de estos intereses. Una, la clásica, que consistiría en reconducir la tutela de estos intereses colectivos a determinadas organizaciones representativas de los mismos en tanto en cuanto todos los interesados formaran parte por ley o por voluntad propia en dicha organización. El portador de los intereses sería así la organización o entidad, que actuaría por medio de sus representantes legales. Así, por ejemplo, ocurre en los supuestos de legitimación institucional corporativa a que se refiere el artículo 32 de la LRJCA, que atribuye legitimación a los colegios oficiales, sindicatos, cámaras, asociaciones y demás entidades constituidas legalmente para velar por intereses profesionales o económicos determinados respecto de estos intereses o derechos. Esta legitimación no excluye la de los coasociados o encuadrados que puedan actuar por sí aislada o litis consorcialmente con la entidad en cuestión ${ }^{30}$.

${ }^{29}$ Cfr. Zanobini, «L'esercizio privato delle funzioni e dei servizi pubbliche», en Primo Trattato completo di Diritto amministrativo italiano, de Orlando, Milán, 1935, pág. 278.

${ }_{30}$ Cfr. Pera Verdaguer, Comentarios a la Ley de lo Contencioso-Administrativo, Barcelona, 1974, pág. 213. 
Sin embargo, es posible que determinadas organizaciones o asociaciones no asuman en su seno como asociados o vinculados a todas las personas que integran el colectivo afectado por esos intereses. Surge entonces el problema de determinar cuál pueda ser la eficacia de la sentencia de acuerdo con las características del contradictorio. Modernamente se tiende a reconocer como portador del interés a entidades o asociaciones, aun de naturaleza privada, a las que se confiere legitimación para gestionar procesalmente estos intereses de clase o de categoría mediante la fórmula del «ente exponencial», es decir, de aquella entidad que asume la representación ideológica de un cierto grupo o colectivo.

Es más, este carácter de portador del interés no sólo se reconoce a entidades, sino a particulares, que, aunque movidos por un interés propio, actúan intereses colectivos. Los procesos adecuados para formalizar estas pretensiones se someten al control de órganos públicos que verifican la seriedad de la reclamación y evitan posibles fraudes o extorsiones. Las modalidades de las relator actions y class actions del Derecho anglosajón son buena prueba de cuanto afirmamos. Sin duda que tanto el Ministerio Fiscal como el Ombusdman (en nuestra versión, Defensor del Pueblo) tienen en este campo grandes perspectivas de actuación ${ }^{31}$.

\section{LA LEGITIMACION PARA RECURRIR EN AMPARO \\ ANTE EL TRIBUNAL DE GARANTIAS CONSTITUCIONALES}

El artículo 123 de la Constitución de 1931 enumeraba los órganos y personas legitimadas para la interposición de los recursos de inconstitucionalidad y de amparo, sin una delimitación precisa de los supuestos atribuibles a cada uno de estos. Excluidos los jueces y Tribunales, el Gobierno de la República y las regiones españolas (núms. $2 .^{\circ}, 3 .^{\circ}$ y $4 .^{\circ}$ del precepto), que, por su propia naturaleza, parecían referidos exclusivamente al recurso de inconstitucionalidad, quedaban como casos con características comunes a ambos el Ministerio Fiscal y «toda persona individual o colectiva, aunque no hubiera sido directamente agraviada» ${ }^{32}$.

La práctica introducción en el número $5 .^{\circ}$ de una acción popular, a consecuencia de una enmienda (el Anteproyecto se refería a personas agraviadas y a entidades a quienes las leyes reconozcan el carácter de organismos de Derecho público, y el Proyecto a las personas agraviadas), suscitó luego vivos recelos que motivaron la restricción interpretativa, dada a dicho artículo en su desarrollo legal ${ }^{33}$. Lo curioso fue que este giro interpretativo - forzado dado el texto del precepto- se tradujo en impedir la acción popular en materia de

${ }^{31}$ Cfr. Almagro Nosete, Nuevos borizontes del derecbo a la justicia, cit., pág. 38.

${ }^{32}$ Sobre los antecedentes de este precepto en el Anteproyecto de la Comisión jurídica asesora y el Proyecto de Constitución, véase J. L. García Ruiz, El recurso de amparo en el Derecho español, Madrid, 1980, obra en extremo útil que incorpora a su texto las sentencias dictadas por el Tribunal de Garantías en materia de amparo.

${ }^{.33}$ Cfr. Almagro Nosete, Justicia constitucional, Madrid, 1980, pág. 18. 
inconstitucionalidad, transformando el recurso de inconstitucionalidad en una excepción de inconstitucionalidad, que podría implantarse sólo por el agraviado, y en mantener la acción popular para el recurso de amparo, aunque con los matices que después señalaré.

La solución no dejaba de resultar paradójica, pues, justamente en una gradación de aptitudes, no ofrece dudas que la naturaleza abstracta de las normas, sin perjuicio de los agravios concretos que puedan derivarse de los actos de aplicación, se presta técnicamente mejor al reconocimiento de la acción popular que la naturaleza concreta de los agravios directamente afectantes a un derecho constitucional, aunque, como indicaremos en su momento, una legitimación limitada al titular (quien alegue la titularidad) resulta en esta materia demasiado restringida. Quedaba también excluido el Ministerio Fiscal, cuya legitimación expresa se reservaba para el planteamiento de las cuestiones sobre inconstitucionalidad.

En efecto, el artículo 47 de la Ley del Tribunal de Garantías, de 30 de junio de 1933, establecía que podría interponer el recurso de amparo de garantías constitucionales la persona que se considerara agraviada o cualquier ciudadano o persona jurídica; cuando el recurrente no fuera el agraviado debería prestar la caución que la Sala acordase ${ }^{34}$.

Temas polémicos, por las enmiendas que al texto se presentaron y por las interpretaciones doctrinales, previas y posteriores, fueron el referente a la legitimación de los extranjeros y de las personas jurídicas. En cuanto a los extranjeros, la distinción respecto de los nacionales aparece con toda nitidez en el precepto: tienen legitimación en cuanto puedan invocar un agravio inferido a una garantía constitucional que tenga reconocida; a diferencia de los nacionales, no pueden ejercitar la acción popular, regla plausible si se tiene en cuenta el carácter político que conlleva la atribución de acción popular al ciudadano. En cuanto a las personas colectivas, los debates parlamentarios se centran en la imposibilidad sostenida por algún sector de que éstas puedan asumir la representación de los intereses de sus afiliados o en la necesidad, sostenida por otro, de reconocer derechos propios a estas entidades. La fórmula dejaba en el aire multitud de cuestiones interpretativas ${ }^{35}$.

Más que las vicisitudes o efemérides de este Derecho histórico nos interesan las enseñanzas que del mismo se extraen para aplicarlas a nuestra realidad presente. Dos aspectos debo resaltar en este sentido, y en ambos me valdré de las palabras del comentarista de justicia constitucional de la época, el mexicano Rodolfo Reyes, que tan útiles e inestimables informaciones y sugerencias nos ha proporcionado a todos los estudiosos de estas materias en su conocida obra La defensa constitucional:

${ }^{34}$ Reyes Rodolfo, La defensa constitucional, Madrid, 1934. «Es notorio - dice- cómo se diferencia el criterio legal en el caso de inconstitucionalidad y en éste del amparo; allá sólo el titular del derecho que resultare agraviado por la aplicación de la ley, sea quien fuera ese titular; aquí la parte agraviada, una persona jurídica, un ciudadano $y$, siendo tercero, dando caución; aquí, naciendo la cuestión correlativa de quiénes pueden ser sujetos de garantías amparadas, cuando allá basta que lo sean de posible aplicación de la ley.\$

${ }_{35}$ Cfr. García Ruiz, ob. cit., pág. 109. 
1. La insuficiencia, en buena doctrina, de la legitimación referida exclusivamente al titular agraviado. Si se puede discutir sobre la conveniencia o no de reconocer la acción popular en una materia que, por afectar a derechos, aunque éstos sean de naturaleza constitucional y pública, puede prestarse a inmisiones abusivas, ya que no en las titularidades, que normalmente son irrenunciables, al menos en las modalidades de su ejercicio es más pacífico, de acuerdo con una filosofía social superadora de un individualismo a ultranza, que la legitimación concebida en términos cerrados puede provocar situaciones reales de indefensión. Dice en este sentido el autor citado: «La razón principal dada para reconocer el carácter popular de la acción de amparo es la de que es muy posible que en virtud del atentado mismo esté impedido de ejercitarla el titular. La legislación mexicana resolvió esta contingencia real dejando en principio la acción al quejoso y por excepción a los parientes o extraños... dando expresa capacidad a las personas morales privadas y a las oficiales cuando actúen como entidades jurídicas, aceptando francamente la jurisprudencia de que puede pedir el amparo el Ministerio Público.» Y cita a pie de página, como «precioso antecedente», el carácter amplio de la legitimación de amparo en el privilegio general aragonés ${ }^{36}$.

2..$^{\circ}$ La necesidad de abrir paso a una tutela de cobertura que supla las deficiencias de las directas por medio de la potenciación de lo que pueden denominarse «asociaciones intermedias». En efecto, frente al esquema lineal del liberalismo individuo-Estado, los nuevos criterios sociales de la época, que arrastran, sin embargo, toda la inercia de formación de esta concepción políticosocial, manifiestan ya la tendencia a la protección de los intereses de clase y colectivos mediante su adecuada protección jurisdiccional. El autor, que confiesa haber formado su juventud «bajo el pleno imperio de la filosofía liberal individualista», señala la distinción que establece, en la tesis que presentó para la oposición a la cátedra de Derecho constitucional en la Universidad Nacional de México, entre «entidades morales formadas por asociaciones de individuos para fines de utilidad pública» que no gozan de garantías individuales y los «seres morales» constituidos por «conjuntos de intereses individuales sumados en los que ni en su naturaleza ni en sus miras desaparecen los individuos que lo forman». Apunta aquí el autor a la moderna distinción entre intereses generales e intereses sociales de grupo o colectivos. No es explicable -dice más adelante, recogiendo la opinión de Daniel Aguilar- «que la acción que se da a uno no se dé a dos o tres juntos» ${ }^{37}$.

${ }^{36}$ Idem, $o b$. cit., pág. 244 y nota 1. Sobre las últimas cuestiones citadas nuestro experto es el profesor Fairén, que ha estudiado exhaustivamente los procesos individuales aragoneses de manifestación. Señalemos, entre otros, sus estudios «Consideraciones sobre el proceso aragonés de manifestación de personas en relación con el babeas corpus británico», en $R e$ vista de Derecbo procesal iberoamericana, Madrid, 1963, núm. 1, pág. 9; «Los procesos medievales aragoneses y los derechos del hombre», en Anuario de Derecho aragonés, $\mathrm{t}$. XIV, 1968-69, págs. 345 y sigs.; Antecedentes aragoneses de los juicios de amparo, México, 1971.

${ }^{3} \mathrm{Ob}$. cit., pág. 251 . 


\section{LA LEGITIMACION PARA RECURRIR EN AMPARO EN MEXICO Y EN ALEMANIA (R. F.)}

\section{A) En México}

El recurso de amparo mexicano, institución compleja que ofrece múltiples facetas, se instituye, prescindiendo ahora de otros antecedentes, en los artículos 103 y 107 de la Constitución de 1917. Estos preceptos han sido desarroIlados en distintas leyes reglamentarias. La Ley de Amparo fue reformada por Decreto legislativo de 20 de marzo de $1976^{38}$.

El régimen de legitimaciones establecido parte de una regla general que limita al quejoso o sujeto agraviado el derecho a impugnar el acto lesivo. La legitimación activa, pues, se deduce, según expresa Burgoa, de lo que dispone el artículo $4 .^{\circ}$ de la Ley que considera a todo sujeto perjudicado por la ley o actos reclamados habilitado para ejercitar la acción respectiva ${ }^{39}$. Los supuestos normales de representación, tanto legal como voluntaria, están previstos por el citado precepto. Se regulan también casos de representación extraordinaria, que denomino así en cuanto que no responden a los mecanismos habituales de la representación. En efecto, en las causas criminales, el defensor puede promover el amparo; se admite también en los casos en que la ley diga expresamente que puede actuar por el agraviado un pariente, incluso un extraño, sin necesidad de que exista formalizada una representación voluntaria o legal. Estos casos se refieren a supuestos de imposibilidad del agraviado y exigen la ratificación posterior del mismo.

Por las personas morales actúan sus representantes. El Ministerio Público Federal está legitimado para intervenir en los juicios de amparo. Se discute sobre el carácter de esta intervención, según se configure al mismo como parte en pie de igualdad con las demás o se le asigne sólo la función de «parte equilibradora».

Especial interés revisten las modalidades de legitimación en materias sociales, tales como las agrarias, causa de las últimas reformas legislativas. Nos referimos a la legitimación de los «núcleos de población» para instar el amparo con finalidad protectora de las clases campesinas. Cualquier ejidatario o comunero, en defecto del comisariado o de los miembros del mismo, puede interponer el recurso contra el acto lesivo ${ }^{40}$. Es en esta transición del amparoqueja individual al amparo-queja grupo social donde comienza a perfilarse, según algunos autores, una evolución de este instrumento hacia la protección de las «garantías sociales». «¿De qué sirve —se pregunta Juventino V. Castroun derecho social que no es accionable en la misma forma? ${ }^{41}$.

${ }^{33}$ Cfr. Fix Zamudio, «El derecho de amparo en México y en España», en Revista de Estudios Políticos, enero-febrero, 1979, pág. 239.

${ }^{39}$ Cfr. Ignacio Burgoa, El juicio de amparo, México, 1978, pág. 354.

${ }^{40} \mathrm{Cfr}$. Noriega, Lecciones de amparo, México, 1975, pág. 579.

${ }^{41}$ Cfr. Juventino V. Castro, Hacia el amparo evolucionado, México, 1977, pág. 79. 


\section{B) En Alemania (R. F.)}

El equivalente al recurso de amparo o queja constitucional (Verdassungsbeschwerde), como instrumento de protección de los derechos humanos, no figuraba en el primitivo texto de la Ley fundamental de 1949. Fue introducido por la Ley sobre el Tribunal Constitucional Federal de 1951 en los parágrafos $90-96^{42}$.

Cualquiera que afirme la lesión de algún derecho fundamental propio está legitimado para interponer el recurso. No puede ser interpuesto en favor de otro, ni siquiera como gestión fiduciaria. Sin embargo, el requisito de afección del propio derecho no es interpretado siempre en forma restrictiva, sino con criterios pragmáticos. Von Munch, a quien seguimos en este breve resumen (ob. cit., nota anterior), alude a dos resoluciones que admitieron el recurso, una, relativa a la cuestionalidad de una ley que beneficiaba a un competidor del recurrente; y otra, en la que el votante de un partido consideró lesionado su derecho electoral porque el partido resultó perjudicado con ocasión de unas elecciones parlamentarias. Revelan estas resoluciones una expansividad de la interpretación jurisprudencial en torno al concepto de derecho subjetivo, ya puesta de relieve por García de Enterría a propósito de la legitimación contencioso-administrativa que lleva a fórmulas prácticas análogas a las del concepto de interés legítimo ${ }^{43}$. La afección del derecho del recurrente se exige sea actual, inminente y personal.

En cuanto a las personas jurídicas, se distingue entre personas jurídicas internas y personas jurídicas en general. Las primeras se benefician de derechos fundamentales propios concordes con sus fines. Las personas jurídicas extranjeras carecen de este amparo. No obstante, el Tribunal Constitucional reconoce en favor de éstas la protección de los derechos procesales. Las corporaciones o entidades de Derecho público que persiguen objetivos públicos carecen en general de derechos frente al Estado. Se admiten excepciones respecto de aquéllas vinculadas en forma inmediata con una actividad protegida por un derecho fundamental (órganos de RTV, universidades estatales o corporaciones religiosas).

${ }^{42}$ Cfr. Fix Zamudio, «Protección de los derechos humanos en Europa continental», en Boletín mexicano de Derecho comparado, núm. 35, 1979, pág. 364 . La última redacción de la Ley del Tribunal Constitucional Federal es de 3 de febrero de 1971. Existe un reglamento interno aprobado por el Pleno del Tribunal de 3 de julio de 1975; véase Von Münch, «EI recurso de amparo constitucional como instrumento jurídico y político en la República Federal de Alemania», en Revista de Estudios Políticos, enero-febrero, 1979, nota 2, pág. 270.

${ }^{43}$ Cfr. García Enterría-T. R. Fernández, Curso de Derecho administrativo, cit., pág. 40. 


\section{LA LEGITIMACION EN NUESTRO ACTUAL PROCESO CONSTITUCIONAL DE AMPARO}

\section{A) La legitimación en el texto constitucional}

Establece la vigente Constitución española, en el ya citado artículo 162.1.b, que están legitimados para interponer el recurso de amparo toda persona natural o jurídica que invoque un interés legítimo, así como el Defensor del Pueblo y el Ministerio Fiscal.

Inicialmente no figuraba entre los legitimados el Ministerio Fiscal. Sobre este punto he dicho en otro trabajo: «Entre los órganos legitimados para promover el recurso de amparo ante el Tribunal Constitucional se ha incluido también al Ministerio Fiscal, según modificación introducida por el Senado, puesto que no figuraba así en el texto aprobado por el Congreso. Nos parece bien que también el Ministerio Fiscal pueda promover el recurso de amparo... Que existan diversos criterios para velar por el Estado de Derecho no significa duplicación innecesaria cuando las funciones de los órganos respectivos nacen históricamente de exigencias distintas y prácticamente responden a especializaciones funcionales diferentes ${ }^{4}$.

Consideremos cada caso por separado:

\section{a) Personas naturales}

No distingue la Constitución entre nacionales y extranjeros a estos efectos. En principio ambos están equiparados, pues no se menciona la cualidad de la ciudadanía como nota diferencial. Sin embargo, esta apariencia debe analizarse conforme a la naturaleza de los derechos amparables según la Constitución y con las menciones específicas que la Constitución dedica a los extranjeros. Conforme al artículo 13 de la Constitución, «los extranjeros gozarán en España de las libertades públicas que garantiza el presente título (o sea, el título I: 'Derechos y deberes fundamentales') en los términos que establezcan los tratados y la ley. Solamente los españoles serán titulares de los derechos reconocidos en el artículo 23 (relativo al derecho a participar en los asuntos públicos) salvo lo que, atendiendo a criterios de reciprocidad, pueda establecerse por tratado o por ley para el derecho de sufragio activo en las elecciones municipales». Algunas otras excepciones pueden encontrarse en la Constitución en relación con determinados derechos fundamentales (principio de igualdad ante la ley - art. 14-, derecho a elegir libremente residencia y a circular por el territorio nacional -art. 19- y derecho de petición) ${ }^{45}$.

Los extranjeros, en cuanto titulares de los derechos que se les reconocen, pueden, pues, solicitar su amparo.

44 Cfr. Almagro Nosete, «El Derecho procesal en la nueva Constitución», en Revista de Derecbo procesal iberoamericana, núm. 4 , octubre-diciembre 1978, pág. 886.

${ }^{45}$ Cfr. Gómez-Reino Carnota, «Las libertades públicas en la Constitución», en Lecturas sobre la Constitución española, I, Madrid, 1978, pág. 48. 
Ahora bien: conforme al precepto constitucional, no es preciso que se afirme como producida, a quien solicita la tutela, la violación de uno de los derechos amparables; basta con que se invoque un interés legítimo. Dada, pues, la configuración del objeto de este proceso constitucional, los terceros ajenos a la titularidad del derecho interesados legítimamente en la reparación del agravio están legitimados para promover el recurso de amparo. Problema cuestionable es el de determinar si los extranjeros sin legitimación directa para solicitar la tutela de un derecho que la Constitución o la ley no les reconozca o les limite pueden legítimamente interesarse en la defensa de un derecho ajeno.

\section{b) Personas jurídicas}

Las personas jurídicas son admitidas, superadas viejas concepciones, como sujetos aptos para recabar el amparo. Conviene, no obstante, que maticemos los aspectos, pues la potencialidad del precepto y su fuerza expansiva, prudentemente controladas por el Tribunal Constitucional, propician una sugetidora gama de posibilidades. Obviamente, está comprendida en el precepto la tutela de los derechos propios de estas entidades (sin que la Constitución distinga entre personas jurídicas de naturaleza pública o privada). Si se analizan, no obstante, los derechos amparables, llegaremos a la conclusión de que muy pocos de éstos se refieren directamente a las personas jurídicas, aunque algunos hagan mención expresa de aspectos atinentes a las mismas y otros requieran de justa interpretación analógica, según sus fines. Esto es, que donde el desarrollo de la actividad de las personas jurídicas muestra su más cabal perfil es en el campo de los intereses profesionales, de categoría, de grupo, colectivos y aun difusos - tan legítimos como los individuales- pertenecientes a sus afiliados e incluso a quienes, no afiliados, mantengan homogeneidad de intereses con aquéllos.

\section{c) Defensor del Pueblo}

El Defensor del Pueblo u Ombusdman hispánico, en palabras de González Deleito ${ }^{46}$, ofrece rasgos de originalidad que he destacado ${ }^{47}$; en conjunto ha dado lugar a una interesante literatura ${ }^{48}$. No es mi intención ahora ocuparme detenidamente de esta institución. Señalaré algunos aspectos atinentes al tema. Constitucionalmente, incumbe al mismo la defensa de los derechos compren-

* Cfr. González Deleito, Tribunales constitucionales. Organización y funcionamiento, Madrid, 1980, pág. 63.

${ }_{47}$ Cfr. Almagro Nosete, El Derecho procesal en la nueva Constitución, cit., pág. 885, y en «Tres breves notas sobre Derecho procesal constitucional», en Revista de Derecho procesal iberoamericana, julio-diciembre 1979, pág. 691.

${ }^{4}$ Cfr. Antonio La Pérgola, «Ombusdman y Defensor del Pueblo», en Revista de Estudios Politicos, cit., pág. 79; Hull Pont, «El Defensor del Pueblo», en Lectura sobre la Constitución española, II, Madrid, 1978; Alberto Pérez Calvo, «El Defensor del Pueblo», en Revista del Departamento de Derecho Politico (UNED), otoño 1979, pág. 79; Gil Robles, El Defensor del Pueblo, Madrid, 1979. 
didos en el Título I de la Ley Fundamental. Incluye este título, como es lógico, los derechos amparables, pero su contenido es más amplio en cuanto que se extiende a otros derechos y en especial a los económico-sociales.

Un sector amplio de las funciones previsibles del Defensor del Pueblo, según los principios que inspiran la proposición de ley publicada en el Boletín Oficial de las Cortes - 20 de junio de 1979, núm. 39- y de acuerdo con criterios doctrinales decantados en líneas generales ${ }^{49}$, no tienen carácter de actuación jurisdiccional. En general, toda la tarea consistente en la remoción de obstáculos administrativos o eliminación o evitación de irregularidades de esta naturaleza, a instancia de las quejas ciudadanas, se desenvuelve primero por vía de investigación y después por medio de persuasión o conciliación para conseguir la satisfacción de los intereses perjudicados, sin que ello sea óbice cuando se adviertan conductas o hechos delictivos que de los mismos se dé cuenta al fiscal general del Estado.

En otro importantísimo aspecto, estas funciones se materializan en el ejercicio del derecho a la jurisdicción por el Defensor del Pueblo, ora sea para ejercitar la acción de responsabilidad contra las autoridades, funcionarios o agentes, ora para interponer, según funciones concretas que establece la Constitución, los recursos de inconstitucionalidad y de amparo. Es bajo esta consideración como nos interesa examinar su actividad. Orgánicamente, su caracterización formal es la de órgano estatal (como alto Comisionado de las Cortes), y su consideración material, la de una magistratura requirente análoga a la del Ministerio Fiscal. Funcionalmente, los intereses que patrocina y bajo cuyo imperativo actúa son intereses generales, sociales, colectivos y aun difusos, aunque en esta materia estos intereses se individualicen cuando actúe exclusivamente pidiendo la tutela de un derecho fundamental.

\section{d) Ministerio Fiscal}

Conforme al artículo 124 de la Constitución, corresponde al mismo promover la acción de la justicia en defensa de la legalidad, de los derechos de los ciudadanos y del interés público tutelado por la ley... y procurar ante los Tribunales la satisfacción del interés social ${ }^{\text {s0 }}$.

49 Durante los días 28 y 29 de febrero de 1980 se celebró en el Centro de Estudios Constitucionales (Madrid) un Seminario Internacional sobre el Defensor del Pueblo en el que participaron: Chozas Bermúdez, Fairén Guillén, Fanjul, Fekik, Legrand, Mac KenzieJohnston, Ollero Gómez, Peces-Barba, Pellón, Pitarch, Ruiz Giménez, Sánchez Agesta, Santín Díaz, Da Silveira, Gil-Robles, Alvaro, Rubio y Almagro Nosete.

${ }_{50}$ Unas consideraciones generales sobre este precepto y posibles líneas de desarrollo en lo que afecta a la vinculación del Ministerio Fiscal puede verse en mi trabajo, ya citado, El Derecho procesal en la nueva Constitución, pág. 865. En lo que respecta a las distintas fórmulas empleadas para caracterizar las principales funciones del Ministerio Fiscal en España, desde la Ley Orgánica de 1870 hasta la fecha: Prieto Castro, Almagro Nosete, González Deleito, Tribunales españoles. Organización y funcionamiento, Madrid, 1979, pág. 87. Un estudio muy completo y reciente de la institución y sus funciones, con amplia bibliografía, Serra Domínguez, «El Ministerio Fiscal», en Revista de Derecho procesal iberoamericana, núms. 3-4, 1979, págs. 609 y sigs. 
Obsérvese el paralelismo entre estas funciones y las que se establecen para el Defensor del Pueblo en cuanto titular de acciones en el plano constitucional. Nada padecerían éstas si se dijera que corresponde al Defensor del Pueblo promover la acción de la justicia constitucional en defensa de la constitucionalidad, de los derechos fundamentales de los ciudadanos y del interés público tutelado por la Constitución. La nota diferencial vendría dada por el rango formal de los preceptos aplicables. Una institución debería moverse en el ámbito de la constitucionalidad (Defensor del Pueblo) y otra en el de la legalidad (Ministerio Fiscal); una tutelaría los derechos fundamentales en cuanto no reconocidos en su verdadera dimensión por la legalidad y otra protegería los derechos de los ciudadanos en cuanto por recto desarrollo de la .Constitución son aplicables. Mas esta diferencia lógica no ha sido tenida en cuenta por la Constitución, pues el Ministerio Fiscal está legitimado para interponer el recurso de amparo ante el Tribunal Constitucional, lo que implica argüir sobre vicios de inconstitucionalidad en las pretensiones que formalice. No se faculta paralelamente al Defensor del Pueblo para que pueda promover el amparo ordinario, es decir, solicitar la tutela de la jurisdicción ordinaria en estas materias. En realidad, lo que estoy planteando es la necesidad de encontrar las mejores soluciones técnicas para establecer las relaciones entre amparo ordinario y amparo constitucional - tema que me preocupa y al que pienso dedicar futuras atenciones- La diferencia objetiva entre tutela de la legalidad y tutela de la constitucionalidad es uno de los vectores más claros en esta materia si no se quiere convertir en un galimatías la regulación de estas cuestiones. A algunos de estos criterios me he aproximado dentro de los límites generales de la obra en Justicia constitucional (ob. cit.). Pero subsisten muchas dudas que dependen de la orientación legislativa y jurisprudencial futura. No son sutilezas ni abstracciones las útiles observaciones que formula a este respecto el tratadista mexicano Fix Zamudio ${ }^{51}$.

\section{B) La legitimación en la Ley Orgánica del Tribunal Constitucional}

\section{a) El cambio del lenguaje}

En los redactores de la LOTC deben haber pesado dudas y vacilaciones lógicas, por supuesto, sobre el sentido de la expresión «interés legítimo», porque, como ponía de relieve J. T. Villarroya al comentar el texto del Anteproyecto constitucional, «esta noción, muy controvertida en la doctrina actual, necesitaría alguna aclaración o precisión» ${ }^{52}$. Sin embargo, la Constitución respetó en los sucesivos proyectos el texto primitivo y, por tanto, ninguna interpretación legal puede, so capa de aclaración, reducir la potencialidad de aquél.

${ }^{51}$ Cfr. Fix Zamudio, Protección de derechos bumanos en Europa continental, cit, página 394.

${ }_{52}$ Cfr. Villarroya, «El Tribunal Constitucional en el Anteproyecto de la Constitución», en Estudios sobre el Proyecto de Constitución, Madrid. 
El artículo 46, al precisar la legitimación para interponer el amparo constitucional, mantiene las menos controvertidas del Defensor del Pueblo y del Ministerio Fiscal y distingue, según el órgano del que provenga el agravio inferido al derecho fundamental tutelable, una legitimación en favor de la «persona directamente afectada» cuando la infracción se produzca por actos del ejecutivo o del legislativo, y una legitimación en favor de "quienes hayan sido parte en el proceso judicial correspondiente» cuando el acto lesivo sea causado por órganos judiciales ${ }^{53}$. Observa González Pérez ${ }^{54}$ que la fórmula interés legítimo de la Constitución ha sido sustituida por la de persona directamente afectada, que parece más limitada que aquélla. Y considera desafortunada e inconstitucional que se refiera en otro supuesto la legitimación a quienes hayan sido parte en el proceso previo, pues debe tenerse presente que no admitir como parte a quien está legitimado es causa de denegación de justicia que motivaría justamente legitimación para recurrir en amparo constitucional.

$\mathrm{He}$ mantenido en mis comentarios a la LOTC ${ }^{55}$ los siguientes criterios:

1. Si la ley ha pretendido reducir el ámbito de la legitimación en determinados casos, conforme al criterio interpretativo sólo tienen interés legítimo quienes'sean personas afectadas, los argumentos que se empleen en apoyo de esta tesis carecerían de fuerza, pues, a sensu contrario - y contando con la primacía de la Constitución sobre la ley-, se puede afirmar que toda persona que tenga interés legítimo está directamente afectada.

2. La reducción que se observa en cuanto a quiénes pueden incoar el proceso de amparo por actos $\mathrm{u}$ omisiones indebidas del Poder Judicial no es admisible. El acto o abstención puede afectar también a un tercero ajeno al proceso donde se produzca.

Pero qué ha ocurrido para que se produzca este giro interpretativo. A mi juicio, se sopesarían por los técnicos que los redactaron los tipos de recurso de amparo o equivalentes conocidos por la doctrina y legislación extranjera (fundamentalmente el modelo germánico y el mexicano), que, desde luego, no refieren la legitimación al interés legítimo, sino que la encastillan en la afirmación de la titularidad del derecho por parte del sujeto agraviado, según hemos podido ver. No obstante, la riqueza interpretativa de estos modelos y los preceptos que modulan el ejercicio de aquella legitimación directa permiten afirmar que se observa una expansividad postulante del tránsito de legitimaciones establecidas con fundamento en la protección de intereses individuales a legitimaciones basadas en la protección de intereses sociales.

Estas razones nos llevan a considerar que acaso no sobra la ambigüedad del concepto «interés legítimo», pues a su tradicional enfoque de interés individual puede añadírsele, sin que el concepto se resienta, la dimensión social. $\mathrm{Y}$ 'si para interesar a otro en una relación jurídica ajena siempre se ha pensado

${ }^{53}$ No podemos analizar en los límites de esta comunicación todos los aspectos legitimantes referidos a intervenciones, sean éstas principales o adhesivas, ni realizar un estudio sobre los supuestos litis consorciales originarios.

${ }^{54}$ Cfr. González Pérez, con cuyas observaciones estamos sustancialmente de acuerdo en Derecho procesal constitucional, Madrid, 1980, pág. 305 .

${ }_{55}$ Cfr. Almagro Nosete, Justicia constitucional, cit., pág. 234. 
en el beneficio que a quien se interesa acarrea y en el respeto que la libertad de ejercicio del propio derecho comporta, no puede olvidarse que en ocasiones el interés por el derecho ajeno puede tener carácter solidario y que la libertad de ejercicio del derecho puede estar anulada o presionada.

\section{b) Interpretación del concepto «interés legítimo» en el amparo constitucional}

Conforme a las ideas que hemos venido exponiendo, sugeriremos ahora criterios de interpretación según los distintos supuestos, teniendo presente que interés legítimo sólo quiere decir interés conforme a derecho.

1. Intereses propios.-La gestión y defensa de los derechos propios, sean éstos de personas físicas (nacionales o extranjeras en cuanto le están atribuidos) o de personas jurídicas (en cuanto conformes a la naturaleza de sus fines), de carácter constitucional, supone la primera base legitimante. Las ventajas o utilidades en beneficio propio o exclusivo que se deriven de un derecho constitucional ajeno son enormemente discutibles en cuanto fundamentadoras de una legitimación principal sustitutiva de la del titular, sea éste persona física o jurídica. Otra cosa sería la operatividad de los mecanismos convencionales de la representación en sus manifestaciones de voluntaria o legal. No obstante, el tema, aun asumidas todas las cautelas, no puede darse apriorísticamente por cerrado. Convendría investigar sobre la naturaleza de cada uno de los derechos fundamentales tutelables, de manera que se distinguieran aquellos aspectos que en cuanto constitutivos de la titularidad son irrenunciables de aquellos otros que se refieran a las áreas de disponibilidad en cuanto a su ejercicio. Si aislaran casos que prácticamente equivalieran a una renuncia del derecho o a una dejación de su ejercicio en perjuicio del tercero, habría que admitir que este tercero (si experimenta detrimento o menoscabo) puede estar legítimamente interesado en evitar aquellas consecuencias dañosas aunque el titular del derecho no actuara. No me refiero, pues, a supuestos de coadyuvancia que siempre son posibles, sino a supuestos de sustitución en defensa de intereses propios.

2. Intereses solidarios.-Llamamos así a todos los que no son propios ni ajenos, sino participativos, sin que el término solidario que se emplea revele solidaridad en el sentido técnico jurídico. Veamos distintos aspectos según sea su portador autorizado o posible en orden a su encuadre para el reconocimiento a los mismos de una legitimación procesal:

2.1. Los intereses generales, sociales, colectivos y difusos, en mayor o menor medida, según los casos y la filosofía que impregne la organización estatal, son asumidos como intereses públicos y para su tutela judicial se acude a diversos medios, sean monopolísticos o concurrentes. En el particular de los derechos fundamentales que nos ocupa, no cabe duda que la Constitución considera de interés público la protección jurisdiccional de los derechos fundamentales, hasta el punto de que no sólo instituye legitimaciones en favor de los 
particulares, sino que establece dos legitimaciones de carácter orgánico-públicas en favor de dos instituciones requirentes de la jurisdicción: una tradicional, el Ministerio Fiscal, y otra de nuevo cuño, el Defensor del Pueblo; en principio, ambas legitimaciones son incondicionadas y creemos que no pueden condicionarse legalmente, pues están reconocidas sin restricciones por la Constitución. No se establece, sin embargo $-\mathrm{y}$ resulta ello conforme a una recta naturaleza de las libertades públicas-, una obligatoriedad en el ejercicio de la acción, como ocurre, por ejemplo, en materia jurídico-penal. Más bien parece que en estos casos la función tiene carácter correctivo o supletorio de la inercia, imposibilidad o dificultad en que se encuentren los titulares de los derechos, esto es, según los casos, deberá valorarse sin conforme a la regla que justifica la tutela que prestan estos órganos procede o no ejercitar la acción. En definitiva, doctrinal, jurisprudencial y reglamentariamente podrán, a mi juicio, determinarse áreas de acción a título indicativo, pues nunca deberán tener carácter limitativo o exhaustivo en relación con la virtualidad del precepto constitucional.

Supuesto, por tanto, que cuando el interés público lo exija o aconseje, tanto el Ministerio Fiscal como el Defensor del Pueblo pueden y deben promover el recurso de amparo constitucional en defensa de cualquier derecho tutelable, con independencia de la acción del titular, parece que estas legitimaciones se orientarán en aseguramiento de la tutela de los derechos fundamentales cuando la lesión o la perturbación afecte a intereses sociales, colectivos e incluso difusos. Esta legitimación de entes públicos con esta finalidad ofrece controversias doctrinales muy características en Italia, donde se ha puesto en tela de juicio la idoneidad del Ministerio Fiscal para tales cometidos ${ }^{56}$, proponiéndose por algunos autores la introducción de órganos nuevos específicos del tipo Ombusdman y otras legitimaciones concurrentes ${ }^{57}$. Con razón, al estudiar los preceptos de nuestra Constitución atinentes a este tema, el mexicano Fix Zamudio manifiesta en relación con esta doble manifestación que «su función debe consistir en la tutela de los derechos fundamentales colectivos o de grupo» ${ }^{58}$. Este carácter colectivo de la «acción» parece que se tiene en cuenta en el párrafo 2 del artículo 46 de la LOTC, que ordena, en los casos en que actúe el Defensor del Pueblo o el Ministerio Fiscal, hacer llamamientos a los posibles agraviados u otros posibles interesados.

Una línea neta de separación entre el área de actuación del Defensor del Pueblo y del Ministerio Fiscal no existe. Funcionalmente pueden, no obstante, sugerirse ideas. Pensamos que mientras el cometido del Ministerio Fiscal se orienta a la conservación del orden jurídico como defensor de la legalidad

\footnotetext{
${ }^{56} \mathrm{Cfr}$. Vigoriti, La legittimazione di enti od organo pubblici, en Interessi collettivi $e$ processo, cit., pág. 235.

${ }^{7}$ Cfr. Cappelletti, «Formazioni sociali e interessi di gruppo davanti alla giustizia civile», en Rivista di Diritto processuale, núm. 3, 1975, pág. 361 .

ss Cfr. Fix Zamudio, El derecho de amparo en México y en España, cit., pág. 259. Su indicación acerca de las class actions o de las relator actions la entendemos como una sugerencia orientadora, por las dificultades de acoplamiento entre aquellos ordenamientos que las acogen y el nuestro. A la irrepetibilidad del fenómeno de la class actions estadounidense se refiere Vigoriti, ob. cit., pág. 251.
} 
(por supuesto en cuanto ajustada a la Constitución), el Defensor del Pueblo se orienta a la promoción y desarrollo del orden jurídico como defensor de la Constitución. Esta caracterización supone una exquisita delimitación por parte del Ministerio Fiscal de lo que sean criterios técnicos y criterios políticos; en cambio, el Defensor del Pueblo puede asumir criterios ideológicos que permitan una razonable expansión de lo jurídico en cuanto constitucional, siempre que estos criterios no se revelen como partidistas y respondan a los objetivos de la Constitución. Comprendo que estas ideas no pueden tener hoy por hoy traducción jurídica reglada, aunque apuntan a vertientes del futuro. Finalmente, incumbe al Ministerio Fiscal ejercitar el recurso de amparo por los menores, incapaces o ausentes que carezcan de representación legal en términos que resultan establecidos estatutariamente en otros casos.

2.2. Los intereses colectivos y difusos, en cuanto intereses legítimos, pueden tener otros portadores distintos del Ministerio Fiscal y del Defensor del Pueblo. Traemos a este lugar el examen de la función que pueden cumplir las personas jurídicas, tanto públicas como privadas, en este aspecto. No desconozco la carga polémica del tema; la lucha por lo asociativo llena la historia social de casi los dos últimos siglos y aún no se ha logrado un relativo equilibrio. Es aquí donde radica, a mi juicio, la importancia del sesgo interpretativo dado por el artículo 46 de la LOTC al artículo 162 de la Constitución. Creo que debe haber influido en este sentido la regulación de la legitimación en la Ley del Tribunal Constitucional Federal Alemán, cuyo parágrafo 90, apartado 1 , refiere ésta a los derechos fundamentales propios del sujeto afectado, lo que motiva que las asociaciones no puedan remediar la lesión de derechos fundamentales inferida a sus miembros ni cuando éstas establezcan como objetivo estatutario la defensa de los derechos de sus miembros ${ }^{59}$. Sin embargo, en la Constitución de la República Federal Alemana no hay un precepto equivalente al nuestro. No se habla de los derechos propios de las personas físicas o jurídicas, ni siquiera de sus intereses legítimos, sino de un interés legítimo. No parece, pues, que constitucionalmente se impongan trabas interpretativas. En efecto, las personas jurídicas ${ }^{60}$ se constituyen para la satisfacción de intereses comunes a todos los asociados o para la satisfacción de intereses supraindividuales que no sólo afectan a ese colectivo, sino que también son comunes a personas no integradas en la misma. En la doctrina jurídica europea está muy viva la cuestión en torno a la fijación de los portadores adecuados de intereses para actuar derechos o situaciones jurídicas solidarias de una determinada clase o grupo. Las organizaciones sobre estos intereses revisten en muchos casos la forma de personas jurídicas. Se habla asi de legitimación de algunos portadores de esos intereses (no a todos se les reconoce) o de representación ideológica de dichos intereses.

${ }^{99}$ Cfr. Von Münch, El recurso de amparo constitucional..., cit., pág. 274.

* No entraremos ahora en la debatida cuestión de la naturaleza pública o privada de éstas, según los casos, ni en la distinción entre corporaciones, asociaciones o fundaciones, ni en los problemas sobre diferencias entre asociaciones de interés público o de interés privado. Véase Albaladejo, Derecho civil I, Introducción y Parte general, Madrid, 1970, página 280. 
En especial se examinan estas cuestiones respecto del proceso civil y proceso contencioso-administrativo. Se entiende, por regla general, que para la consideración de quien es el portador adecuado es preciso cumplir determinados requisitos legales, pero también que deben otorgarse poderes discrecionales al juez para la valoración de las características representativas de la entidad. En el ámbito de los intereses colectivos de trabajo existen ya ejemplos legales. En España es posible hallar algunas de estas disposiciones; así, en el vigente Estatuto de los Trabajadores (Ley 8/1980, de 10 de marzo, BOE de 14 de marzo) se reconoce al comité de empresa capacidad como órgano colegiado para ejercer acciones administrativas o judiciales en todo lo relativo al ámbito de sus competencias por decisión mayoritaria de sus miembros (art. 65), e igualmente, «a efectos de ostentar representación institucional en defensa de intereses generales de los trabajadores o de los empresarios ante la Administración Pública $\mathrm{u}$ otras entidades $\mathrm{u}$ organismos de carácter nacional que la tengan prevista», se entiende que gozan de esta capacidad representativa las entidades sindicales con un determinado porcentaje de afiliados (disposición adicional $6 .^{a}$ ). El Derecho comparado ofrece ottos ejemplos (asociaciones de consumidores, de usuarios de determinados servicios, de protectores del medio ambiente, etc.); con ello pretendemos poner de relieve la tendencia inexorable del Derecho a ampliar los campos de la legitimación a intereses solidarios. En el tema que examinamos ninguna prohibición constitucional -más bien una permisiónexiste para que se reconozca a determinadas personas jurídicas, en representación de esos intereses, legitimación para gestionar el amparo de los derechos de sus miembros y la de todos los sujetos de la categoría o clase afectada ${ }^{61}$.

2.3. Los intereses difusos son aquellos afectantes a un grupo, categoría o clase que carecen de organización. El Derecho moderno no renuncia a la protección de los mismos. En estos casos todos los afectados son portadores del interés y potenciales ejercientes del mismo, aunque llegada la ocasión no todos actúen. La legitimación de categoría o de clase se diferencia de la acción popular en la menor generalidad de su ámbito. $\mathrm{La}$ vinculación de los titulares no se establece en razón de un carácter externo a la situación jurídica objeto de controversia (ciudadanía, vecindad), sino en razón de un interés sustancial común a todos los afectados. El ejemplo más característico es la ya citada class actions, en las que el actor, como miembro de una clase de personas cuyo interés se deduce en juicio, actuando en interés de la clase misma, es investido por el juez del carácter de adecuado representante. No cabe duda que instrumentos jurídicos de esta naturaleza no son apropiados para un sistema jurídico como el nuestro. Sin embargo, no debe rechazarse la hipótesis de construcciones que, tomando base en estas ideas, permitan mediante los pertinentes filtros de Derecho público (por ejemplo, Defensor del Pueblo, una combinación de las class actions y de las relator actions) recrear nuevos instrumentos de tutela.

2.4. El círculo de determinados intereses solidarios puede ser muy restringido (por ejemplo, el ámbito familiar). El interés legitimante para actuar un derecho ajeno debe estar claro en todos los casos en que la incapacidad del

${ }^{61}$ Vigoriti, La legittimazione de alcuni dei titolari, cit., pág. 146. 
mayor de edad o la ausencia, no formalizadas en punto a representación, o un razonable impedimento (que puede obedecer a múltiples causas) no permitan actuar en nombre propio. Esta representación no formalizada del pariente o de persona allegada debe también, a mi juicio, reconocerse como un interés legítimo. 